\title{
Penggunaan Kolase Karir Sebagai Intervensi Terapi Untuk Pengambilan Keputusan Karir Siswa SMK
}

\author{
Diana Dewi Wahyuningsih \\ Universitas Tunas Pembangunan, Surakarta, Indonesia \\ dianadewibagus@gmail.com \\ Imam Setya Nugraha \\ Universitas Tunas Pembangunan, Surakarta, Indonesia \\ imamsetyonugroho@lecture.utp.ac.id
}

\begin{abstract}
Abstrak
Penelitian ini bertujuan untuk menyelidiki penggunaan kolase karir sebagai intervensi terapi untuk pengambilan keputusan karir siswa SMK. Penelitian ini termasuk jenis penelitian penelitian kepustakaan (library research), yaitu, dengan mencatat semua temuan dan memadukan segala temuan baik teori atau temuan baru tentang kolase karir, menganalisis segala temuan dari berbagai bacaan dan memberikan gagasan kritis tentang kolase karir sebagai intervensi terapi untuk pengambilan keputusan karir siswa. Hasil penelitian menunjukkan bahwa Kolase karir merupakan serangkaian kegiatan yang didesain konselor melalui pembuatan papan visi sebagai bagian dari strategi pengekspresian diri siswa untuk membangun identitas diri. Menggunakan kerangka teori karir sosial kognitif, untuk mempromosikan eksplorasi identitas, meningkatkan keyakinan self efficacy dan pengembangan aspirasi karir.
\end{abstract}

Kata kunci: Kolase Karir; Intervensi Terapi; Pengambilan Keputusan Karir.

\section{Abstract}

Use of Career Collage as a Therapeutic Intervention for Career Decision Making for Vocational High School Students. This study aims to investigate the use of career collage as a therapeutic intervention for career decision making in vocational high school 
students. This research belongs to the type of library research, namely, by recording all findings and combining all findings, either theory or new findings about career collage, analyzing all findings from various readings and providing critical ideas about career collage as a therapeutic intervention for decision making. student career. The results showed that career collage is a series of activities designed by counselors through the creation of a vision board as part of students' self-expression strategies to build self-identity. Using a cognitive social career theory framework, to promote identity exploration, increase selfefficacy beliefs and the development of career aspirations.

Keywords: Career Collage; Therapeutic Interventions; Career Decision Making.

\section{A. Pendahuluan}

Karier adalah bagian hidup yang berpengaruh pada kebahagiaan hidup manusia secara keseluruhan. Oleh karenanya ketepatan memilih serta menentukan keputusan karier menjadi titik penting dalam perjalanan hidup manusia. Keputusan memilih suatu karir dimulai saat individu berada pada masa remaja. Pada usia remaja, sekolah merupakan aspek penting dalam kehidupan karena pendidikan menyiapkan mereka dalam kondisi siap untuk mengambil keputusan karir. Seligman dalam Marliyah dkk, (2004) mengatakan bahwa sejumlah karir mulai dibangun dan dikembangkan sejak masa sekolah dan karir dapat juga dikatakan sebagai suatu cita-cita yang diinginkan, baik yang berkaitan dengan suatu bidang pendidikan, pekerjaan maupun suatu profesi tertentu. Remaja adalah peralihan dari masa kanak-kanak menuju masa kedewasaan. Suatu masa yang mempengaruhi perkembangan dalam aspek sosial, emosi, dan fisik. Remaja memiliki tugas-tugas perkembangan yang mengarah pada persiapan memenuhi tuntutan dan peran sebagai orang dewasa. Pada tahap ini, salah satu tugas perkembangan remaja adalah memilih dan mempersiapkan diri untuk menjalankan suatu pekerjaan, serta membuat keputusan karir.

Pada Harian Sinar Harapan (28 Mei 2010), data Susenas 2010 menunjukkan 61\% siswa SMA tidak memahami kemana mereka sebaiknya 
menempuh pendidikan lanjut. Dalam keadaan terdesak seperti ini, remaja mengambil keputusan untuk memilih jurusan dipengaruhi orang tua dan peer group (teman sebaya), dimana saran tersebut bersifat subyektif. Menurut Conger (Marliyah dkk, 2004) salah satu tugas perkembangan remaja adalah pemilihan dan persiapan karir. Pemilihan karir merupakan saat seorang remaja mengarahkan diri pada suatu tahapan baru dalam kehidupan mereka. Membuat keputusan memilih karir merupakan usaha remaja menemukan dan melakukan pilihan di antara berbagai kemungkinan yang timbul dalam proses pemilihan karir.

Remaja mulai membuat rencana karir dengan eksplorasi dan mencari informasi berkaitan dengan karir yang diminati. Setelah remaja mencapai tahap perkembangan kognitif operasional formal (11 tahun - dewasa) yaitu tahap dimana mereka sudah dapat berpikir secara abstrak. Pada fase ini mereka mengeksplorasi berbagai alternatif ide dan jurusan dalam cara yang sistematis, misalnya jika ingin menjadi dokter maka harus memilih jurusan Ilmu Pengetahuan Alam (IPA). Usia remaja dalam teori perkembangan karir Ginzberg termasuk dalam tahap tentatif yaitu dengan usia 11-17 tahun. Tahapan usia ini adalah masa transisi dari tahap fantasi pada anak-anak menjadi pengambilan keputusan realistik pada remaja. Sejalan dengan perkembangan karir tersebut, proses karir telah muncul pada usia sekolah yaitu ketika anak-anak mulai mengembangkan minatnya dan adanya pemahaman keterkaitan antara kemampuan dengan karir dimasa depan.

Menurut Supriatna (2009: 174) masalah karir yang dirasakan siswa SMK adalah: siswa kurang memahami cara memilih program studi yang co cok dengan kemampuan dan minat, siswa tidak memiliki informasi tentang dunia kerja yang cukup, siswa masih bingung untuk memilik pekerjaan, siswa ma sih kurang mampu memilih pekerjaan yang sesuai dengan kemampuan dan minat siswa merasa cemas untuk mendapatkan pekerjaan setelah tamat sekolah, siswa belum memiliki pilihan perguruan tinggi atau lanjutan pendidikan tertentu setelah lulus SMK, siswa belum memiliki gambaran tentang karakteristik, persyaratan, kemampuan dan keterampilan yang dibutuhkan dalam pekerjaan serta prospek pekerjaan 
untuk masa depan karirnya. Salah satu layanan dalam mengatasi permasalahan karir remaja adalah dengan bimbingan dan kons eling.

Tujuan bimbingan dan konseling adalah untuk mengembangkan potensi pada individu seoptimal mungkin, sesuai dengan kemampuan agar bisa menyesuaikan diri dengan lingkungannya, baik lingkungan sekolah, keluarga maupun lingkungan masyarakat (Bastomi, 2020). Menurut Yusuf \& Nurihsan dalam Bastomi (2019) Proses Bimbingan dan Konseling di sekolah dapat berhasil apabila mempunyai tujuan yang jelas yang akan dicapainya. Bimbingan dan konseling bertujuan untuk membantu peserta didik agar dapat mencapai tujuantujuan perkembangannya yang meliputi aspek pribadi-sosial belajar (akademik) dan karir. Sedangkan tujuan bimbingan dan konseling Islam menurut Mubarok dalam Bastomi (2017) Secara singkat dapat dirumuskan sebagai berikut : (1) Tujuan umum Konseling Islam untuk membantu konseli agar dia memiliki pengetahuan tentang posisi dirinya dan memiliki keberanian mengambil keputusan, untuk melakukan suatu perbuatan yang dipandang baik, benar dan bermanfaat, untuk kehidupannya di dunia dan untuk kepentingan akhiratnya. (2) Tujuan khusus bimbingan konseling Islam adalah: (a) Untuk membantu konseli agar tidak menghadapi masalah. (b) Untuk membantu konseli mengatasi masalah yang sedang dihadapinya. (c) Untuk membantu konseli memelihara dan mengembangkan situasi dan kondisi yang baik atau yang telah baik agar tetap baik, sehingga tidak akan menjadi sumber masalah bagi dirinya dan orang lain. Guna mencapai tujuan bimbingan konseling sesuai yang diharapkan tentunya proses manajemen bimbingan dan konseling harus berjalan dengan sangat baik. Dengan layanan bimbingan dan konseling diharapkan siswa dapat melakukan pengambilan keputusan karir secara matang.

Pengambilan keputusan memegang peranan penting pada masa remaja karena akan mempengaruhi kehidupan remaja tersebut seperti pilihan teman, pilihan jurusan serta pemilihan karir kelak. Remaja sering memandang pengambilan keputusan disertai kebingungan, ketidak pastian dan stress. Kebanyakan pengambilan keputusan dibuat oleh para remaja yang mengalami 
perubahan yang menyulitkan dan tak berguna (Santrock, 2007: 56). Super dalam Savickas (2001) menjelaskan bahwa individu dikatakan matang atau siap untuk membuat keputusan karir jika pengetahuan yang dimilikinya untuk membuat keputusan karir didukung oleh informasi yang kuat mengenai pekerjaan berdasarkan eksplorasi yang telah dilakukan. Dalam sebuah penelitian pada individu-individu setelah mereka meninggalkan bangku sekolah menengah atas diketahui bahwa setengah dari mereka tidak sistematis dan tidak memiliki arah dalam eksplorasi dan perencanaan karir mereka (Santrock, 2007: 57).

Siswa sekolah menengah kejuruan berada pada tahap eksplorasi karir yang sudah mampu untuk mengeksplorasi pilihan karir yang lebih realistis. Siswa membutuhkan pengetahuan dan keterampilan dalam menentukan pilihan karir, agar dapat melakukan pengambilan keputusan karir. Membuat keputuasan karir adalah salah satu proses paling kompleks dan menantang sepanjang hidup (Fabio, Pallazzeschi, Perez, \& Gati, 2013). Siswa sekolah menengah kejuruan dihadapkan pada dilematis (Abdinoor, 2019) karna masih banyak siswa sekolah menengah kejuruan yang belum melakukan eksplorasi terhadap karirnya sendiri, karena kurang memperoleh informasi mengenai pendidikan dan keterampilan (Fatimah, Suherman \& Rohaeti ;2019) yang diperlukan untuk melakukan pilihan karir di masa depan.

Setelah lulus sekolah menengah kejuruan, siswa kurang mampu bersaing untuk mendapatkan pekerjaan, kurang mampu bersaing dalam dunia kerja (Gestiada, Nazareno \& Villanueva, 2017), kurangnya motivasi untuk memutuskan memilih jenis pekerjaan (Fitriasari, 2020), dan siswa takut menjadi pengangguran maka asal memilih pekerjaan yang tidak sesuai dengan latar belakang akademis (Bahtiar, soesatya \& hakim, 2017).

Salah satu factor yang berperan besar dalam keputusan karir adalah keyakinan pada kemampuan diri sendiri (self efficacy), yang berperan penting dalam menentukan perkembangan karir di tahap selanjutnya (Lent, Brown \& Hackett, 2000). Self efficacy berkaitan dengan kemampuan dalam menyelesaikan 
tugas, memprediksi tingkah laku selanjutnya (Yowell et. al; 2014), menunjukkan kinerja yang optimal, dan dimana kesuksesan akan memberi pengaruh positif pada efficacy diri untuk tugas - tugas berikutnya (Fatimah, suherman \& rohaeti, 2019), melatih keterampilan self efficacy dapat meningkatkan 45,66\% kemampuan mengatasi masalah dan meningkatkan keyakinan dalam menetapkan pilihan jurusan (Ardiyanti \& Alsa, 2015).

Sejalan dengan konsep teori karir sosial kognitif, yang menekankan pada proses kognitif tentang cara seseorang memikirkan diri sendiri, pola kognitif dan berbagai proses intreraksi sosial untuk membimbing dan memberikan pengaruh pada perilaku seseorang (Bandura, 1989; Lent et al, 1994). Pengambilan keputusan karir menurut teori karir sosial kognitif adalah cara seseorang membuat keputusan karir ditentukan oleh faktor-faktor personal (self efficacy, harapan hasil dan tujuan pribadi) dan pengaruh variable kontekstual yang akan mempengaruhi tujuan dan selanjutnya akan diwujudkan pada bentuk kinerja karir (Bandura, 1986; Lent et al, 1994).

Dalam proses konseling dapat menggabungkan kreatifitas seni, yang dapat memberikan wawasan baru pada klien dan mengarahkan pada perubahan perilaku (Gladding, 2008). Pada proses pelaksanaanya, konselor dapat memahami dan lebih menghargai proses dan usaha dari kreatifitas klien untuk meningkatkan harga diri, memberikan relaksasi, mengajarkan keterampilan koping, dan mengembangkan kesadaran akan emosi (Kennedy, Reed \& Wamboldt, 2014). Pelasanaan ini, dapat memberikan kesempatan kepada klien untuk membentuk pikiran, perilaku dan perasaan mereka menjadi sebuah kekuatan (MacKay, 1989). Menurut Lent et. al, (1994) mengadaptasi unsur-unsur teori sosial kogniti Bandura yang paling relevan dengan proses pengembangan karir untuk menguji pengaruh dan hasil interaksi antara proses pembelajaran berdasarkan pengalaman dan proses kognitif pada keputusan karir.

\section{B. Metode}


Metode penelitian yang digunakan adalah deskriptif korelasional, yaitu suatu metode penelitian yang bertujuan untuk melihat hubungan antara dua variabel atau lebih (Notoadmodjo, 2002). Pengumpulan data menggunakan studi literatur dengan mencari referensi teori yang relevan dengan papan visi untuk meningkatkan keyakinan self efficacy, harapan hasil dan tujuan karir; dapat membantu siswa melakukan pengambilan keputusan karir. Data yang diperoleh akan dianalisis dengan metodr analisis deskriptif. Metode analisis eskriptif dilakukan dengan cara menyusun data dan fakta-fakta yang diperoleh kemudian dianalisis sehingga memberikan informasi yang dibutuhkan.

\section{Pembahasan}

\section{Kolase Karir}

Kolase karir berupa sebuah papan visi digunakan sebagai alat yang fleksibel, multifungsi dan kreatif. Alat ini menggunakan "Papan visi" sebagai alat kreatif dalam bimbingan kelompok dan dapat digunakan untuk mempromosikan komunikasi dan identifikasi tujuan masa depan, dengan berbasis kekuatan diri sendiri (Rubin, 2000) dan focus pada menemukan solusi dari situasi yang dihadapi. Metode penggunaan papan visi dengan nama kolase karir adalah untuk mempromosikan eksplorasi identitas diri (Tibbetts \& Stone, 1990), meningkatkan keyakinan self efficacy dan pengalaman belajar yang dapat digunakan untuk mengidentifikasi kekuatan dan keberhasilan diri (Blomdahl, et.al, 2013). Konselor dapat menggunakan "Papan visi" untuk mempromosikan, mengkomunikasikan dan menetapkan tujuan masa depan (Waalkes, Gonzalez \& Brunson, 2019; McNiff, 1997; Steinhardt, 1985).

Dalam pelaksanaanya papan visi dapat berisikan kumpulan gambar dan dikombinasikan dengan teknik arahan verbal (Schultz, 1984); berupa potongan poster, majalah, foto tokoh dan tulisan yang menginspirasi untuk memunculkan fantasi pada diri klien dalam membuat perencanaan keputusan karir masa depan (Skovholt et.al, 1989). Klien memodifikasi pandangan mereka tentang diri mereka sendiri dengan cara yang berbeda, memanfaatkan pemikiran dengan dituangkan 
pada gambar, tulisan dan menceritakan pengalaman belajar dapat memberikan kekuatan yang menetap dan tahan lama (Kress et.al,2015).

Klien dapat menggunakan papan visi untuk merancang dan merefleksikan pertanyaan yang kompleks dan melibatkan kemampuan imajinatif dan kreatifitas dalam mengutarakan ketidakpastian atau ketidaksesuaian (misalnya: apa yang ingin saya lakukan setelah lulus SMK?; pelatihan apa yang bisa saya ikuti untuk bekal kompetensi diri?) sehingga dapat menyusun perilaku berubahan. Menggunakan kolase karir untuk mengidentifikasi atau mengklaifikasi terkait self efficacy karir siswa (Mosely, 2010), dengan memanfaatkan imajinasi, kreatifitas dan cara berfikir non linier dapat membebaskan siswa untuk memasukkan keinginan terkait ekspektasi hasil dan tujuan karirnya (Waalkes et.al, 2019). Dengan pembuatan "papan visi" dapat membantu siswa membuat jembatan antara kesenjangan antara keyakinan self efficacy dan perencanaan karir di masa depannya.

Konselor dapat menggunakan kolase karir yang berupa papan visi ini untuk memperomosikan, mengkomunikasikan dan membantu siswa menetapkan tujuan karir masa depan (Burton \& Lent, 2016); untuk mengidentifikasi dan mendiskusikan aspirasi pendidikan dan karir (Wiggins \& Tingley, 2015). Konselor dapat melaksanakannya dengan cara mendiskusikan terutama yang berkaitan dengan arahan dalam hidup (Gladding, 1988), kegiatan dibuat terstruktur di mana konselor dapat memberikan pedoman untuk menumbuhkan imajinasi siswa (Heppner et.al, 1994).

Manfaat dari penggunaan kolase karir dalam konseling karir adalah (Skovholt et. al, 1989): (a) mengajarkan pada siswa tentang fleksibel dalam berpikir, (b) mengembangkan proses pemikiran yang berbeda dan generalisasi lebih banyak pada pilihan karir, (c) mempertimbangkan dan menikmati prosesnya dari aspek - aspek non rasional dalam pengambilan keputusan dan (d) aman, tanpa paksaan dan murah dalam pembuatanya. 
Konselor sekolah dapat dengan sengaja menyusun pengalaman belajar ini sesuai dengan perspektif teori karir sosial kognitif (Lent et. al, 1994), membangun pengalaman dengan membuat kolase karir dapat memberikan pengaruh pada keyakinan self efficacy, ekspektasi hasil positif, menumbuhkan minat dan menetapkan tujuan. Saat ini siswa menuju pemahaman diri, orientasi pada diri sendiri menuju masa depan, dengan cara eksplorasi karir dan akademis dapat menjadi bagian penting dalam memahami perkembangan karir. Dengan menggunakan kolase karir, konselor dapat membantu siswa mengeksplorasi dirinya sendiri dan mengembangkan identitas serta memperkuat self efficacy dengan cara membangun pemikiran positif pada kemampuan diri. Sesuai program layanan konseling di sekolah, menurut ASCA (American School Counseling Association, 2012, 2014) konselor sekolah dapat menggunakan papan visi sebagai komponen kreatif yang dapat membantu siswa mencapai persiapan memasuki perguruan tinggi dan karir.

Pembuatan kolase karir dapat dibantu konselor dengan membuatkan perintah - perintah yang memungkinkan siswa untuk mengidentifikasi kekuatan dan keyakinan akan keberhasilan mereka, meningkatkan keyakinan self efficacy, mengekspresikan minat-minat yang sesuai, membuat urutan pilihan karir dan membayangkan keberhasilan karir yang sesuai dengan identitas diri siswa. Papan visi dapat membantu siswa merefleksikan diri dan mengekspresikan secara verbal melalui tulisan-tulisan, sehingga memungkinkan siswa mengeksplorasi dan berproses dengan situasi yang ada tanpa menentukan jawaban" yang benar" dari pilihan karir yang dibuat (Burton \& Lent, 2016). Dalam layanan di sekolah kegiatan ini dapat terjadwal dan berorientasi pada tugas, sehingga siswa dapat menikmati kegiatan ini dengan berekspresi dan kreatif. Papan visi bersifat terbuka dan berbasis kekuatan, memungkinkan siswa untuk mengeksplorasi dan membangun konsep diri yang positif.

Menurut Gladding (2016) Konselor sekolah dapat menggunakan papan visi untuk mengadvokasi siswa atau memperkuat keinginan-keinginan yang tidak selalu dapat terwujud, termasuk dilingkungan sekolah. Semisal siswa dengan latar 
belakang ekonomi rendah, dari keluarga dengan orang tua yang diktator atau penyandang disabilitas. Dapat mengartikulasikan aspirasi siswa melalui papan visi dengan cara mendorong pihak sekolah untuk menanggapi secara proaktif dan memberikan dukungan.

\section{Pengambilan Keputusan Karir}

Secara historis model-model pengambilan keputusan berasal dari ilmu ekonomi. Asumsi pokok kebanyakan beraal dari teori ekonomi Keynesian, adalah bahwa orang memilih suatu tujuan karir atau sesuatu okupasi untuk memaksimalkan keuntungan dan meminimalkan kerugian. Untung dan rugi tidak hanya diukur dengan uang, akan tetapi hal yang lebih bermakna bagi individu. Okupasi atau jalur karir tertentu dapat dipandang sebagai alat untuk mencapai keinginan tertentu, seperti gengsi yang tinggi, keamanan, pasangan, termasuk didalamnya adalah harapan bahwa individu dapat dibantu memprediksi akibat dari setiap alternatif serta peluang yang ada (Manrihu, 1992: 86).

Super dalam Manrihu (1992: 87) menyatakan bahwa karir sebagai suatu sekuensi posisi-posisi yang diduduki seseorang selama hidupnya. Selain itu, Flanagan dan Cooley dalam Manrihu (1992: 87) juga menyatakan bahwa karir sebagai suatu pohon kehidupan (Decision tree) yan melukiskan titik keputusan yang dihadapi seseorang melalui sekolah sehingga memasuki dunia kerja; sebagai suatu rangkaian tahap-tahap kehidupan dimana berbagai konstalasi tugas-tugas perkembangan yang dihadapi dan dijumpai.

Pengambilan keputusan karir merupakan sebuah proses dalam memilih sebuah pekerjaan (Zunker, 2012: 204). Sedangkan menurut Brown dan Brooks mendefinisikan pengambilan keputusan karir sebagai sebuah proses pemikiran seseorang dalam mengintegrasikan atau menggabungkan pengatahuan tentang dirinya dengan pengetahuan suatu pekerjaan untuk membuat pilihan berkaitan dengan karir. 
Sukardi (2008: 89) menyatakan bahwa pengambilan keputusan karir merupakan suatu proses dimana seseorang mengadakan suatu seleksi terhadap beberapa pilihan dalam rencana masa depan. Sejalan dengan pendapat dari Munandir (1996: 98) menyatakan bahwa keputusan karir yang dimaksud adalah keputusan yang diambil secara arif dan penuh telaah serta penuh pertimbangan. Pengambilan keputusan seperti ini mutlak demi keberhasilan dalam hidupnya kelak dengan karir yang dipilihnya tersebut.

Teori pengambilan keputusan karir menurut Tiedeman dan O'Hara (1992: 88) menyatakan bahwa identitas karir individu terbentuk oleh pengambilan keputusan yang menjadi sasaran pemahaman dan kehendak individu. Pengambilan keputusan merupakan upaya untuk membantu individu untuk menyadari semua faktor yang melekat pada pengambilan keputusan sehingga mereka mampu membuat pilhan-pilihan yang didasarkan pada pengetahuan tentang diri dan informasi lingkungan yang se suai.

Pengambilan keputusan karir menurut Hartono (2016: 123) adalah suatu proses dinamis dan berkelanjutan untuk membuat pilihan karir dari beberapa alternatif pilihan karir yang ada dimasyarakat, berdasarkan hasil pemahaman diri (self-knowledge) dan pemahaman karir (occupational knowledge). Setiap manusia pada dasarnya menginginkan kesejahteraan hidup. Untuk mencapai keinginan itu, dibutuhkan persiapan karir yang memadai, diantaranya daam hal pengambilan keputusan karir, sehingga karir yang dipilihnya merupakan keputusan tepat bagi dirinya. Ketepatan pengambilan keputusan karir didasarkan pada kesesuaian antara apa yang dimiliki dan apa yang diinginkan (Hartono, 2016: 124).

Tiedeman dan O'Hara dalam Sharf (2012: 204) mengemukakan bahwa terdapat empat aspek dalam pengambilan keputusan karir, yaitu :

a. Eskplorasi Aspek ini merupakan sebuah proses eksplorasi terhadap kemungkinan pilihan keputusan yang akan diambil oleh seseorang. Melalui fase ini seseorang akan memahami dengan jelas konsekuensi akan sebuah keputusan. 
b. Kristalisasi Aspek kristalisasi merupakan stabilisasi dari sebuah pemikiran seseorang. Pada fase ini pemikiran dan perasaan mulai terbentuk secara permanen sehingga keyakinan atas pilihan yang diambil menguat. Hal tersebut membuat alternatif pilihan semakin jelas.

c. Pemilihan Aspek pemilihan merupakan fase organisir pelengkapan dan penyesuaian terhadap pilihan karir sehingga seseorang semakin yakin dan percaya terhadap pilihannya.

d. Klarifikasi Klarifikasi merpakan proses meyakikan kembali ketiga aspek terdahlu ketika seseorang mulai kebingungan terhadap keputusannya yaitu esksplorasi, kristalisasi, dan pemilihan terhadap alternatif lain.

Sedangkan Menurut Gati, dkk., (2010) terdapat sebelas domain dalam pengambilan keputusan karir, yaitu 1) pengumpulan informasi, 2) lokus kontrol, 3) usaha, 4) prokrastinasi, 5) kecepatan membuat keputusan akhir, 6) konsultasi dengan orang lain, 7) ketergantungan dengan orang lain, 8) hasrat untuk membahagiakan orang lain, 9) cita-cita ideal, 10) kesediaan untuk berkompromi.

Marliyah (2004) menjelaskan bahwa terdapat dua faktor yang dapat mempengaruhi pengambilan keputusan karir yaitu :

a. Faktor Internal Faktor internal merupakan faktor yang disebabkan dari dalam dirinya sendiri. seperti intelegensi, bakat, minat, sifat-sifat kepribadian, keadaan fisik, nilai-nilai kehidupan serta pengetahuan.

b. Faktor Eksternal Faktor eksternal adalah faktor yang disebabkan dari luar diri seseorang. Antara lain dipengaruhi oleh status sosial, ekonomi, keluarga, pengaruh dari keluarga khususnya orangtua, pendidikan sekolah, teman sebaya, serta latar belakang budaya.

Sedangkan menurut Mitchell dan Krumboltz dalam Rahmat., dkk (2014), faktor-faktor yang mempengaruhi pengambilan keputusan karir individu antara lain adalah : (a) Sumbangan Genetis Faktor ini terdiri dari penampilan fisik seperti tinggi badan, warna rambut, warna kulit, kecenderungan terhadap penyakit fisik 
tertentu, dan lain-lain. (b) Kondisi lingkungan dan Kejadian-kejadian Kondisi lingkungan dalam hal ini meliputi faktor sosial, kondsi pendidikan, dan kondisi pekerjaan. (c) Pengalaman Belajar Pengalaman belajar terdiri dari dua jenis yaitu pengalaman belajar instrumental dan pengalaman belajar asosiatif. (d) Ketrampilan Menghadapi Tugas Ketrampilan mengerjakan tugas dapat dijelaskan sebagai kemampuan atau pemahaman seseorang dalam melakukan pengambilan keputusan yang terdiri dari penetapan tujuan, penetapan alternatif, klarifikasi nilai, dan mendapat informasi karir.

\section{Proses Mempersiapkan Dan Memfasilitasi Pembuatan Kolase Karir}

Berikut ini adalah uraian proses mempersiapkan dan memfasilitasi pembuatan kolase karir dengan menciptakan pembuatan papan visi. konsep pada layanan ini berupa bimbingan kelompok, konselor dapat dengan mudah mengadaptasi sebagai intervensi secara berkelompok, untuk waktu dan tempat pelaksanaan dapat disepakati bersama siswa.

a. Konselor mengembangkan instrumen angket pengambilan keputusan karir berbasis teori karir sosial kognitif, untuk menganalisis siswa dengan kemampuan pengambilan keputusan karir rendah. Instrumen ini disampaikan sebelum kegiatan bimbingan kelompok untuk mengetahui kemampuan pengambilan keputusan karir, di awal kegiatan (Pre test).

b. Konselor membuat petunjuk khusus dengan tujuan agar siswa mampu mengekspresikan dan mengembangkan kreatifitas sebagai wujud identitas diri, yang akan dituangkan pada papan visi. Konselor mempersiapkan tugas siswa dengan mengisikan jurnal individu berupa deskripsi untuk mengetahui hambatan dan dukungan yang diterima.

c. Siswa diminta untuk mempersiapkan triplek, kardus atau gabus digunakan untuk papan visi. ditambah bahan - bahan lainnya berupa poster, majalah, tabloid, kertas warna - warni, spidol, pendil warna, lem, gunting, selotip, pita, stiker, dls). 
d. Untuk refleksi awal, konselor dapat membuat pertanyaan yang memungkinkan siswa dapat bediskusi dan bertukar pendapat dengan teman sebaya tentang identitas mereka. Misalnya: “ apa yang membuat saya unik?” atau "hal apa saja yang dapat saya raih dalam 20 tahun ke depan?". Konselor meminta siswa untuk menempelkan, pertanyaan yang dijawab di selembar kertas danditempelkan dibelakang papan visi mereka. Dengan pertanyaan ini, konselor dapat meminta siswa untuk menjelaskan arti papan visi yang mereka buat, untuk mengidentifikasi komponen - komponen penting dari identitas diri (seperti: minat, nilai, tujuan, pendukung, dls) dan untuk memberikan nama pada tujuan masa depan mereka (misalnya: di masa depan saya ingin menjadi.....). Mintalah siswa untuk memasukkan hal - hal yang spesifik, tujuan jangka pendek yang akan membantu siswa mencapai tujuan jangka panjang. Untuk refleksi akhir, buat pertanyaan yang meminta siswa untuk merefleksikan proses terkait papan visi yang dibuat dan mengidentifikasi langkah-langkah kecil yang konkret yang akan membantu siswa mencapai tujuan mereka. Misalnya " hal tersulit apa yang akan kamu temui untuk mewujudkan tujuan karir kamu?" atau “ pertimbangan apa yang kamu pilih untuk menggunakan gambar ini dalam papan visi kamu?".

e. Selama proses kegiatan, diakhir pertemuan mintalah siswa untuk mengisi jurnal individu atau melalui diskusi. Untuk merefleksikan pengalaman belajar sebelumnya terkait dengan pemilihan karir (misalnya: kegiatan kelas, kunjungan industri, karyawisata, workshop, pengaruh keluarga dan teman sebaya, dls) yang berhubungan dengan identitas mereka dan masa depan. Pengalaman belajar di masa lalu dapat membantu siswa untuk menerapkannya dalam papan visi, sesuai dengan teori karir sosial kognitif bahwa pengalaman belajar dapat memberikan dukungan pada penetapan tujuan karir.

f. Konselor memberikan petunjuk yang dapat membantu siswa untuk memahami tujuan dari layanan bimbingan kelompok ini (misalkan: untuk membantu siswa "mewakili gambaran diri") Ajaklah siswa untuk 
menciptakan papan visi mereka dengan cara yang unik yang dapat mewakili seperti apa diri mereka. Pertimbangkan untuk menunjukkan kepada teman sebaya papan visi yang sudah dibuat mendapatkan masukan, sehingga siswa dapat memiliki gambaran untuk merealisasikan papan visi yang dibuat.

g. Memberikan waktu dan dukungan kepada siswa untuk dapat merealisasikan papan visi. Pantau terus prosesnya dan tawarkan dukungan. Bila setelah kegiatan siswa merasa ada hal penting yang perlu didiskusikan dengan konselor maka dapat dilanjutkan dengan sesi konseling. Untuk mengetahui perubahan atau keefektifan intervensi ini dapat diukur dengan instrumen angket pengambilan keputusan karir diakhir kegiatan atau Post test.

h. Perkenankan siswa untuk menyimpan papan visi mereka dan memajang di tempat yang terlihat (kamar tidur, ruang kelas atau di ruang tengah) untuk mengingatkan mereka tentang tujuan karir mereka. Dorong siswa untuk membagikan papan visi mereka dengan orang-orang penting dalam kehidupan mereka, agar siswa mendapatkan dukungan untuk merealisasikan impian mereka.

\section{Implikasi dan Pertimbangan Kolase Karir dalam Pengambilan Keputusan Karir Siswa SMK}

Pembuatan papan visi sebagai bagian dari kolase karir dapat memberikan dampak positif pada self efficacy dan ekspektasi hasil, terutama bila dikombinasikan dengan adanya dukungan sosial secara positif untuk mengeksplorasi identitas diri pada siswa. Menggunakan papan visi, ditambah adanya keyakinan self efficacy dan pilihan identitas diri dapat mendorong siswa untuk membuat daftar panjang tentang spesifikasi tujuan jangka pendek yang ingin dicapai, dan menentukan pilihan perilaku untuk mencapai tujuan tersebut. Sejalan dengan teori karir sosial kognitif, penetapan tujuan dapat membantu siswa dalam mengeidentifikasi kemampuan dalam diri dan membentuk munculnya perilaku baru. Konselor dapat membantu siswa untuk mulai memikirkan perilaku, yang diperlukan untuk mencapai tujuan. 
Untuk memfasilitasi ini, konselor dapat menantang siswa dengan keyakinan self efficacy rendah untuk mulai mencoba kemungkinan - kemungkinan baru. Konselor dapat menanyakan kepada siswa tentang hambatan yang mungkin terjadi dan bagaimana siswa dapat mengatasinya, hal ini untuk mengetahui kekuatan akan keyakinan self efficacy dalam diri siswa. Papan visi juga dapat berfungsi untuk membantu siswa yang secara sosial berada pada kondisi distigmatisasi, maka perlu adanya penegasan identitas. Konselor dapat mengajak anggota lain untuk membantu siswa dengan berbagi pengalaman terkait dengan minat, dukungan, hambatan dan tujuan dari anggota lain agar siswa dapat yakin akan kemampuannya. Penting bagi konselor untuk dapat menciptakan lingkungan dimana siswa dapat membuat papan visi mereka dengan istilah mereka sendiri, terutama untuk siswa yang khawatir akan penilaian dari teman - temannya. Konselor dapat mengingatkan kepada siswa bahwa kegiatan ini bukanlah kegiatan evaluasi yang akan mendapatkan kritikan dari orang lain, melainkan sebagai wujud ekspresi siswa untuk menuangkan ide - ide sesuai keinginannya.

\section{Simpulan}

Kolase karir merupakan serangkaian kegiatan yang didesain konselor untuk memfasilitasi siswa dalam mengekspresikan pilihan karir dimasa depan melalui penyusunan papan visi. Papan visi adalah alat yang fleksibel untuk mendorong siswa mengembangkan identitas diri dan kemampuan untuk emnentukan pilihan pendidikan atau karirnya, menginspirasi dengan menuangkan ide - ide yang kurang terwakili. Konselor sekolah dapat menggunakan papa visi untuk mempromosikan siswa sekolah menengah kejuruan dalam menentukan pilihan karir dan kesiapan memasuki perguruan tinggi. Pembuatan papan visual ini dapat dilakukan dalam layanan konseling kelompok, individu maupun bimbingan kelompok. Siswa dapat mengekplorasi topik - topik yang berorientasi pada perencanaan masa depan dengan lebih terbuka, khususnya siswa yang mengalami hambatan dalam pengembangan karir. Menciptakan papan visi adalah cara unik bagi siswa untuk memunculkan kekuatan dan membuka kesadaran akan kemungkinan untuk mengembangkan diri di masa depan. 


\section{DAFTAR PUSTAKA}

Abdinoor, N. M \& Ibrahim, M.B. (2019). Evaluating Self Concept, Career Decision Making Self Efficacy and Parental Support As Predictors career maturity of Senior Secondary Students From Low Income Environment. European Journal of Education Studies. Vol. 6, no. 7. 2019. doi: 10.5281/zenodo.3529843.

American School Counseling Association, (2012). The ASCA National Model: A Framework for School Counseling Programs (3rd ed). Alexandria, VA: Author.

American School Counseling Association, (2014). The ASCA National Model: A Framework for School Counseling Programs (3rd ed). Alexandria, VA: Author.

Ardiyanti, D \& Alsa, A. (2015). Pelatihan "PLANS" untuk Meningkatkan Efikasi Diri dalam Pengambilan Keputusan Karir. Gadjah Mada Journal of Professional Psycchology. Volume 1, No. 1, April 2015: 1-17.

Bahtiar, M. D, Soesatya, Y \& Hakim, L. (2017). The Influence of Locus of Control, Self Efficacy, and Accounting Achievement Learning on Accounting career Maturity of The Twelfth Grade Students of The Accounting Program in Private Vocational High Schools. International Journal of Education. Vol. 10. No. 1, August. 2017, pp. 53-59.

Bandura, A. (1989). Social Cognitive Theory. In R. Vasta (Ed), Annalis of Child Development. Vol. 6. Six Theories of Child Development (pp. 1-60). Greenwich, CT: JAI Press.

Bastomi, H. (2017). Menuju Bimbingan Konseling Islami. KONSELING EDUKASI: Journal of Guidance And Counseling, 1 No. 1. https://doi.org/10.21043/konseling.v1i1.4434

Bastomi, H. (2019). Konseling Cyber: Sebuah Model Konseling Pada Konteks Masyarakat Berbasis Online. Konseling Edukasi: Journal of Guidance and Counselling, 3, No. 1.

Bastomi, H. (2020). Pemetaan Masalah Belajar Siswa SMK Negeri 3 Yogyakarta Dan Penyelesaiannya (Tinjauan Srata Kelas). KONSELING EDUKASI : Journal of Guidance And Counseling, 4 No. 1.

Blomdahl, C, Gunnarsson, A. B, Guregard, S \& Bjorklund, A. (2013). A Realist Review of Art Therapy for Clients With Depression. The Art in Psychotherapy. 40 (2013). 322-330. doi:https://doi.org/10.1016/i.aip.2013.05.009

Burton, L \& Lent, J. (2016). The Use of Vision Boards as a Therapeutic Intervention. Journal of Creativity in Mental Health, 11, 52-65. doi: 10.1080/15401383.2015.1092901

Fabio, A. D, Pallazzeschi, L, Perez, L. A \& Gati, I. (2013). Career Indecision Versus Indecisiveness: Associations With Personalityy Traits and Emotional Intelligence. Journal of Career Assessment. 21 (1) 42-56. 
Fatimah, S, Suherman, M.M \& Rohaeti, E.E. (2019). Pelatihan penerapan Metode PLANS Untuk Mengembangkan Efikasi Diri Dalam Pengambilan Keputusan Karir Siswa Kabupaten Purwakarta. Jurnal Bimbingan dan Konseling Islam. Vol. 9, No. 2, 121-130.

Fitriasari. F. (2020). The Influence of Entrepreneurship Subject on Students Entrepreneurial Intention. International Journal of Advances in Social and Economics. Vol. 2, (2). doi: https://doi.org/10.33122/ijase.v2i2.105

Gati, I., Landman, S., Davidovitch, S., Peretz, L. A., \& Gadassi, R. (2010). From career decision-making styles to career decision-making profiles: A multid imensional approach. Journal of Vocational Behavior, 76, 277-291.

Gestiada, G, Nazareno, A \& Villanueva, R. M. R. (2017). Development of a Senior High School Creer Decision Tool Based on Social Cognitive Career Theory. Philippine Journal of Science. 146 (4): 445-455

Gladding, S. T. (2008). The Impact of Creativity in Counseling. Journal of Creativity in Mental Health, 3, 97-104. doi: 10.1080/15401380802226679.

Gladding, S.T. (1988). Counseling As An Art: The Use of The Expressive Art in Counseling. Paper Presented At The Conference of The American Association for Counseling and Development, Chicago, IL..

Gladding, S.T. (2016). The Creative Arts in Counseling. Fifth Edition. Alexandria, VA: American Counseling Association. Library of Congress Cataloging-inPublication Data.

Hartono. (2016). Bimbingan Karir. Jakarta: Prenadamedia Group.

Heppner, M. J, O’Brien, K.M, Hinkelman, J.M \& Humphrey, C.A. (1994). Shifting The Paradigm: The Use of Creativity in Career Counseling. Journal of Career Development, 21, 77-86.

Kennedy, H, Reed, K. \& Wamboldt,M.Z. (2014). Staff Perceptions of Complementary and Alternative Therapy Integration Into a Child and Adolescent Psychiatry Program. Arts in Psychotherapy, 41,221-26.

Kress, V. E, Adamson. N, Demarco. C, Paylo. M. J \& Zoldan, C.A. (2015). The Use of Guided Imagery As An Intervention In Addressing non-Suicidal Self-Injury. Journal of creativity in Mental Health,8, 35-47.

Lent, R. W, Brown, S.D \& Hackett, G. (1994). Toward a Unifying Social Cognitive Theory of Career and Academic Interst, Choice, and Performance. Journal of Vocational Behaior, 45, 79-122. doi:10.1006/jvbe.1994.1027

Lent, R.W, Brown. S. D \& Hackett, G. (2000). Contextual Supports and Barriers to Career Choice: A Social Cognitive Analysis. Journaln of Counseling Psychology. Vol. 47, 1, 36-49.

Manrihu, M. T. (1992). Pengantar Bimbingan dan Konseling Karier. Jakarta: Bumi Aksara.

Marliyah, L., \& Dewi, F. I. (2004). Persepsi terhadap Dukungan Orang Tua dan Pembuatan. Keputusan Karir Remaja. Jurnal Provitae, 1 (1).

Munandir. (1996). Program Bimbingan Karir di Sekolah. Jakarta: Depdikbud.

Rahmat, D., Wahyuni, E., \& Herdi. (2014). Faktor-faktor yang mempengaruhi pengambilan keputusan karir mahasiswa jurusan bimbingan dan konseling. Insight Journal, 3(2). 
Santrock, J. W. . (2007). Remaja Jilid 1. Jakarta: Penerbit Erlangga.

Savickas, M. L. (2001). A Developmental Perspective on Vocational Behaviour: Career Patterns, Salience, and Themes. International Journal for Educational and Vocational Guidance, 1.

Sharf, R. (2012). Applying Career Development Theory to Counseling. California: Brooks/Cole Publishing Company.

Sukardi, D. K. (2008). Pengantar Pelaksanaan Program Bimbingan dan Konseling di Sekolah. Jakarta: Rineka Cipta.

Supriatna, M. (2009). Layanan Bimbingan Karir di Sekolah Menengah. Bandung: UPI Press.

Zunker, G. V. (2012). Career counseling a holistic approach (8th ed.). USA: Brooks/ Cole Cengage Learning.

Tibbetts, T. J \& Stone, B. (1990). Short-Term Art Therapy With Seriously Emotionally Disturbed Adolescents. Art in Psychotherapy, 17, 139-146.

Waalkes, P. L, Gonzalez, L. M \& Brunson, C. N. (2019). Vision Boards and Adolescent Career Counseling: A Culturally Responsive Approach. Journal of Creativity in Mental Health. 14, 205-216, doi: 10.1080/15401383.2019.1602092.

Wiggins, C. R \& Tingley, K. (2015). Bridging the Gap To Form Meaningful Connections Between Underrepresented Minority High School Students and Wildlife Science Professionals. IZE Journal, 51, 15-18.

Yowell, E. B, MccConnell, A.E \& Schedin, E. A. (2014). Decided and Undeccided Students: Career Self Efficacy, Negative Thinking and Decision Making Difficulties. NACADA Journal. Vol. 34 (1). 2014. 